\title{
Khaldunian Techniques of Historical Criticism and their Place in Modern Debates on Naqd al-Matn (Content criticism) of Hadith *
}

\author{
Ibn Halduncu Tarih Eleştiri Teknikleri ve Bunların Modern \\ Hadis Içerik Eleştirisi (Nakd'ül-metin) \\ Tartışmaları Üzerindeki Yeri
}

\author{
Salahudheen Kozhithod \\ Darul Huda Islamic University, India \\ salhu.dheen@gmail.com
}

\begin{abstract}
Techniques of Historical criticism developed by Ibn Khanldun in his seminal work alMuqaddimah are well-known. However, he himself admitted that they are not applicable as such to Hadith criticism instead it should be done by applying techniques of Jarh wa al-Ta'dil (criticism of chain of narration). Nevertheless he rejected many popular ahadith such as the ahadith on advent of Imam Mahdi and Pophetic Medicine. One of the major accusations of the western scholars such as Goldziher was that the early hadith scholars had not applied historical criticism in hadith rather they were exclusively sticking to sanad criticism. Many contemporary Muslim scholars are very much influenced with this criticism and stand for a free and open content criticism of Hadith which creates a tendency to reject several well-authentic ahadith of the Prophet. Here the researcher examines the possibility of applying techniques of historical criticism in hadith and it also examines why Ibn Khaldun differentiated between hadith and history whereas Historiography and hadith are both historical account reported through certain chains of narrators. As both are mainly known to us through narration, they are prone to misrepresentations and misinterpretations. It uncovers that to some extent the Khaldunian Techniques are applicable to hadith along with sanad criticism but unlike contemporary scholars they did not stand for an open and free criticism.
\end{abstract}

Keywords: Khaldunian Techniques, Historical Criticism, Modern Debates

Öz: Ibn Haldun'un ufuk açıcı Mukaddimesi'nde gelişstirdiği Tarihsel Eleştiri Teknikleri çok iyi bilinmektedir. Ancak, kendisinin de kabul ettiği gibi bunlar bu şekilde hadis çalışmalarına uygulanamaz. Bunun yerine, hadiste cerh ve tadil (isnad zincirinin eleştirisi) metodu

\footnotetext{
*This article is a review of the paper presented at the "4th International Ibn Khaldun Symposium" organized on 19-21 May 2017 in Istanbul.
} 
uygulanmaldır. Bununla birlikte, Ibn Haldun Mehdi'nin gelişi ve nebevi tıpla ilgili pek çok popüler hadisi reddetmiştir. Goldziher gibi Batılı alimlerin en büyük eleştirilerinden biri, ilk hadis alimlerinin hadislerde tarihsel eleştiri metodunu kullanmak yerine senet eleştirisini kullanmış olmalarıydı. Günümüz Müslüman alimlerden pek çoğu bu eleştiriden etkilenerek içerik eleştirisini savunmuş, bu durum da pek çok sahih hadisin reddedilmesi eğilimini yaratmıştır. Bu yazı hadislerde tarihsel eleştiri tekniklerinin uygulanabilirliğini incelemektedir. Yazıda ayrıca tarih yazıılığının da hadislerin de tarihi beyanlar olduğu ve her ikisinin de uzun ravi zinciri ile aktarılıyor olduğu düşünüldügüünde neden ibn Haldun'un tarih ilmini hadisten ayırdığı sorgulanmaktadır. Oysa her ikisi de rivayet yoluyla bize ulaştığı için yanlış beyan ve yoruma açıktır. Sonuç olarak, Ibn Halduncu metotların bir ölçüde senet eleştirisiyle birlikte hadislere uygulanabileceği ortaya konmakta fakat bunun günümüz alimlerinin iddia ettiği gibi bir eleştiriyi kastetmediği iddia edilmektedir.

Anahtar Kelimeler: Ibn Halduncu Metot, Tarihsel Eleştiri, Modern Tartışmalar

\section{Different Nature of Hadith and History: Khaldunian Perspective}

Everyone can easily understand Khaldunion opinion regarding the nature of a particular science, because he had elaborated on classification of knowledge in his seminal work Muqaddimah. Therefore, determining the differences and similarities between hadith and history, no doubt, it should start from his classification of knowledge. Ibn Khaldun classified all sciences into two major divisions: philosophical and transmitted while history is among the philosophical sciences and hadith is among the transmitted.

What Khaldun meant by Philosophical and the transmitted is clearly understood from his own explanations. To him the former means "ones with which man can become acquainted through the very nature of his ability to think and to whose objects, problems, arguments, and methods of instruction he is guided by his human perceptions, so that he is made aware of the distinction between what is correct and what is wrong in them by his own speculation and research, in as much as he is a thinking human being"(Ibn Khaldun, 1980, 436) Whereas he described the latter as depending "upon information based on the authority of the given religious law. There is no place for the intellect in them, save that the intellect may be used in connection with them to relate problems of detail with basic principles."(Ibid.) In short there is no place for intellect in hadith rather we should depend upon narrations and chain of narrations as it is elaborated in the works of hadith criticism.

He has reemphasized this difference while elaborating on historical critical methods. He says: "It is superior to investigations that rely upon criticism of the personalities of 
transmitters. Such personality criticism should not be resorted to until it has been ascertained whether a specific piece of information is in itself possible, or not. If it is absurd, there is no use engaging in personality criticism. Critical scholars consider absurdity inherent in the literal meaning of historical information or an interpretation not acceptable to the intellect, as something that makes such information suspect. Personality criticism is taken into consideration only in connection with the soundness (or lack of soundness) of Muslim religious information, because this religious information mostly concerns injunctions in accordance with which the Lawgiver (Muhammad) enjoined Muslims to act whenever it can be presumed that the information is genuine. The way to achieve presumptive soundness is to ascertain the probity ('adalah) and exactness of the transmitters. On the other hand, to establish the truth and soundness of information about factual happenings, a requirement to consider is the conformity (or lack of conformity of the reported information with general conditions). Therefore, it is necessary to investigate whether it is possible that the (reported facts) could have happened. This is more important than, and has priority over, personality criticism." (/bid., 18) Through this he stands for differentiating between nature of hadith and history. History tells how things were; hadith primarily tells how things should be. In other words, hadith, being part of revelation, has a legal binding to prescribe how things should be performed within the broad spectrum of history.

In other words one is divine centric to certain extent and the other is human centric. According to Ibn Khaldūn, history is an "information about human social organization, which itself is identical with world civilization." In terms of its subject matter, "it deals with such conditions affecting the nature of civilization as, for instance, savagery and sociability, group feelings, and the different ways by which one group of human beings achieves superiority over another. It deals with royal authority and the dynasties that result (in this manner) and with the various ranks that exist within them. (It further deals) with the different kinds of gainful occupations and ways of making a living, with the sciences and crafts that human beings pursue as part of their activities and efforts, and with all the other institutions that originate in civilization through its very nature."(Ibid., 71).

His conception of hadith was introduced along with the discussion of revelation and the prophetic experience. As he explains, the prophets are humans but endued with inspiration from God to guide their fellow human beings aright. According to him, the phenomenon of wahy (revelation) to prophets, attested by the mu'jizah (miracles) 
which are not within the ability of human, indicates that "there exist things beyond the reach of man, that can be learned only from God through the mediation of these individuals."(Ibid., 184). In the state of wahy, prophets were endowed with the ability to slough off humanity and were immersed in spiritual kingdom, foreign to the ordinary human perception. As soon as this state is over, prophets would bring what they have learned back down to the level of human perception. (Ibid., 185-199) Being an integral part of revelation, prophetic hadith then emanates from the same extraordinary experience.

\section{Interplay between Hadith and History}

Even though hadith and history are of different nature they have some common grounds. hadith could be considered as part of the history of the Prophet and his companions. It is within the compass of history that prophetic hadith unfolded, studied and emulated. History, i.e. the history of the Prophet (Sirah) was considered as part of hadith which is commonly defined as "what was transmitted on the authority of the Prophet, his deeds, sayings, tacit approvals, or description of his physical features and moral behaviour". (Itr, 1990, 12) The Prophetic history was started by the birth of hadith and it developed within the domain of hadith until it was treated as separate discourse. However both have different scopes. While the Sirah is focused on the history "hadith compilation revolve not only around history but also and mainly around the religious and legal implications of the Prophet Muhammad."(Uri Rubin, 1998, xxiv)

Likewise, Historiography developed in Islam along with the development of sciences of hadith and the early chronicler of the Prophet's military engagements with his adversaries (maghäzi) were largely scholars of hadith. As a result, rules of hadith criticism to ascertain the authenticity of the report were equally employed to historical narrations, and the science of isnād or chains of transmission developed in the science of hadith, became central to historiography. It is then the curiosity of the early scholars to document the biography of the Prophets (sirah) to collect his sayings, deeds and approvals, coupled with the historical accounts narrated in the Qur'ān aroused. It strengthened the interests of the early Muslim generations in studying the broader history of mankind of which the Prophetic history occupied a prominent segment.

\section{HCM of Ibn Khaldun to Evaluate the Conformity of History}

To pursue the critical investigation of historical information, Ibn Khaldūn proposes that one must distinguish (a) the conditions that attach themselves to the essence of 
civilization as required by its very nature; (b) the things that are accidental to civilization and cannot be counted on; (c) and the things that cannot possible attach themselves to it. Then we shall have normative method for distinguishing right from wrong and true from falsehood in historical information.(Ibn Khaldun, 1980, 77).

In the pre-Khaldūnian era, history was considered as mere reports of the past events thus anything else rather than the personal criticism was not relevant to it. The Khaldūnian new concept of history challenged this and by bringing history from the domain of the 'transmitted' knowledge he approached it as a speculative science that will make possible for historians to reach the truth itself and to avoid the many errors of historical research. Lack of such a scientific historiography has created many errors and fallacies in the historical accounts recorded by the historians prior to him. In an attempt to investigate these errors, Ibn Khaldūn has listed the causes that often led historians to such kind of historical fallacies as follows:

Information that people accept without critical investigation due to their partisanship to a particular school or opinion causes historical fallacies and blunder.

One of the examples for such kind of fallacies, is the denial of historians the descent of the Ubaydid (Fatimids), the Shī' $\mathrm{T}$ Caliphs in al-Qayruwan and Cairo from Imam Ismā'īl, the son of Ja'far al-șādiq. Ibn Khaldūn observes that they base themselves in this respect on stories that were made up in favour of the weak Abbasid caliphs by people who wanted to ingratiate themselves with them through accusations against their active opponents. (Ibid, 40-43)

Reliance upon transmitters who were unaware of the purpose of an event. Many transmitters do not know the real significance of his observations or of the things he has learned orally.

The stories that historians recorded which accuse Yahyā ibn Aktham and al-Ma'mūn of drinking wine and having inclination for young men could be related to this factor. To Ibn Khaldūn, this kind of recordings happened in history because the historians did not look to the motives behind this stories which perhaps were an invention of Yahyā's 's enemies, for he was much envied because of his perfection and his friendship with the ruler. Furthermore, Yahyā ibn Aktham was atransmitter of hadith and was praised by Ibn Ḥambal and Judge Ismāīl. Tirmidhī recorded ahādīth on his authority.(/bid., 38-39) 
The information made public about high ranking persons may not be truthful because people, as a rule, approach such people with praise and encomiums. Human souls long for praise, andpay great attention to this world, positions and wealth instead of desire for virtue and virtuous people.

The stories of Tubba', As'ad Abu Karib, who lived in the time of the Persian Kayyanid king Yastasb could be considered as an example for fallacies occurred due to the above causes. (Ibid., 21-25) Ibn Khaldūn was critical of this information relying on valid historical facts and geographical realities.

1) Another reason is the ignorance of how conditions conform to reality. Conditions are affected by ambiguities and artificial distortions. The informant reports the conditions as he saw them but on account of artificial distortions he himself has no true picture of them. The story of Alexander in which he was prevented Alexander from building Alexandria by Sea monsters which is recorded by Mas'ūdī has been considered as one of such fallacies. Ibn Khaldūn refuted this story for various reasons such as: rulers would not take such a risk; the jinn are not known to have specific forms and effigies. They are able to take on various forms; anyone who goes down deep into the water, even in a box would have too little air for natural breathing...(Ibid., 72-74). Therefore, the incident could not have been possible within such socio-historical context.

2) Disregard for the fact that conditions within the nations and races change with the change of periods and the passing of days. This is the case with individuals, times, and cities, and, in the same manner, it happens in connection with regions and districts, periods and dynasties. (/bid., 56-57).

One of the examples of fallacies occurred in this way, is the historians' illustration of the father of Hajjāj as a school teacher. As Ibn Khaldūn remarks, teaching in the early days was a noble and commendable action, not how it came to be during the later time when it became profession of lower standard. Such are the patterns of Ibn Khaldūn's re-reading of the historical accounts. Some of these patterns can shed light on historical dimension of the Prophetic hadith or help in the right understanding of its import.

\section{HCM of West in Content Criticism of Hadith}

In the west modern methods to study the past is commonly referred to as Historical Critical Method (HCM) which emerged from Renaissance Humanism and critical 
approach to the sources of history and religion that subsequently developed in Germany in the eighteenth and nineteenth centuries. That means to not approach what historical sources tell us without doubt and question. To them the default setting is scepticism and thus everything should be questioned. As the great German historian Leopod von Ranke declared "history is about looking behind the sources to find out what really happened".

This critical method took root in Europe and blossomed in the Universities of Germany in the eighteenth and nineteenth centuries. The new German school of history assumed that the first step of studying any text was to question its reliability and establish its authenticity. In other words the default setting for scholars was to doubt the reliability of material transmitted about the past. Along with this priori doubt about textual reliability, the German school of history rested on other revolutionary methodological foundations. The European enlightenment had produced materialistic understanding of the world in which events proceeded according to natural laws and not according to divine intervention. As a result, history could not be explained by God's direct involvement or miracles. Instead, it was the immutable laws of human society that shaped human history. (Brown, 2010, 197-208).

The major difference is clear from here, that they included all religious sciences among the Philosophical sciences as part of history. They studied hadith within the sphere of history which is nothing but a philosophical scince where HCM is easily applied.

Here the researcher would like to analyse few examples from Goldzihers seminal work, Muslim Studies. In the articles, he divided the hadith into two; political and nonpolitical. By political he means the ahadith which are directly or indirectly supports any of the following groups prevailed at the time of Umayyads and the early part of Abbasids who had a certain political position.

1) Those who insisted people to not fight against a government according to Goldziher the major portion of them were Murjites. "They did not consider the virtual rejection of religious laws by the Umayyads as sufficient reason to refuse obedience even theoretically or to brand them as kafir but it was sufficient to consider them as rulers that they professed Islam in general. He further argued that "they were expected to declare the opponents of the dynasty and the abettors as unbelievers". He further elaborated the loyal accommodation of Murjites with Umayyad rule. 
2) The author brings evidences to prove that "the politico-religious opponents of Umayyads mainly adopted the party of Alids" and therefore they were the opponents of Murjites as well. He elaborated the enmity between these two sects.

3) Between these two extreme trends there is a middle party or mediating theologians. They spread the doctrine that obedience was in all circumstances duet to the de facto rulers in the interest of the state and unity of Islam.

4) Khawarijites, who regarded it as their duty to fight against the rulers, but they were against appointing Ali and his successors as rulers.

He further argued that to sustain the power a lot of 'calming hadith' were invented to teach that even if a wicked government must be obeyed and it must be left to God to cause the downfall of the rulers whom he disapproves. Two major accounts of such narrations are Kitab al-Kharaj of Abu Yusuf and Kitab al-Siyar of Muhammad ibn alHasan al-Shaybani. Example of such narrations:

1) Prophet said: "Every emir is to be followed into war whether he be just or not and the salat must be performed behind any Muslim, be he just or wicked.

2) "Obey your superiors and resist not, for to obey them is to obey God, to rebel against them is to rebel against God."

3) Likewise the narrations that exhorted not join any party in times of political rebellions and revolutions such as "The seated one is better than he who stands, the standing better than he who walks, the walker better than he who strives."

4) To this belong those traditions which exhorts and comforts the believers by saying that "if it is not possible to alter prevailing evil with hand and tongue it is sufficient to protest with heart"

According to Goldziher, they endeavoured to find out practical examples from the ancient history of Islam to support the above mentioned theoretical views, such as:

1) Ahnaf ibn Qays I set forth in order to help this man (i.e. Ali before the battle of camel) I met Abu Bakrah and he said: Where are you going? 'I want to go and help this man' countered Abu Bakrah and I heared the Prophet say: 'If two Muslims draw swords against one another, both the murder and murdered will go to the hell.'

After narrating this group of narrations he added that they "were listed without chronological order, since in the absence of chronological criteria of even relative certainty, it is impossible to establish one. It may be supposed, however, that the basic idea of this group of hadith goes back to the first century when the contrast between 
the spirit. (Goldziher, 1969, 39-89) He further argued that the Muslim scholars did not do the content criticism as the west did with hadith.

\section{How did Ibn Khaldun Applied HCM in Content Criticism of Hadith?}

We have already explained that Ibn Khaldūn placed the hadith and its sciences among the transmitted sciences and he recognized the importance of the continuous chains of narration to ensure its authenticity due to the revelational nature of the prophetic discourse. However, it does not follow that all transmitted reports regarding the Prophetic life and commentaries upon the Qur'ān fall in the category of the sciences of divine nature. Rather, there are many reasons to suggest that fallacies may creep into these sciences through misunderstanding of the report. In such cases a critical eyes of historians is very much needed to remove these transmitted sciences from errors. From this point of view, the causes of historical errors discussed above could be extended to certain extent to the discourse of hadith. The following remarks and reservation of Ibn Khaldūn on certain hadith and its nature will show the relevance of his historical method to the hadith.

It must be made clear that Ibn Khaldūn when explaining the prophetic experience focused more on the supernatural dimension of prophethood. However, when discussing categories of different sciences, he identified very vividly other dimensions of prophets. He made it clear that while the divine revelations the prophets brought are unquestionably true, other things they do as required by their humanity could be the subject of historical examination. (Ibn Khaldun, 1980, 184).

\subsection{Prophetic Medicine}

Major compilations of hadith such as Sahih of Bukhari and Muslim consist of chapter of Prophetic Medicine and many still regard it as methods of cure. However, in Ibn Khaldūn's classification Medicine belongs to a category of sciences different from hadith. While the former is put under intellectual philosophical sciences, the latter is put under religious, transmitted sciences. From the outset, Ibn Khaldūn drew literally and accepted word by word the Prophetic hadith that proclaims "The stomach is the home of disease. Dieting is the main medicine. The origin of every diseaseis indigestion."In his commentaries upon this hadith, he explained that the food one consumes compounded with air pollution is the main root of all illness. The people of the towns eat more food and do less exercise and live in an environment full of air pollution. As they become more vulnerable to illness, they need more medicine to cure their illness. Inhabitants of desert, by contrast, do not suffer a similar illness. They are 
accustomed to scarcity and lead a simplistic life with less pollution. They eat natural food at their disposal and take their fresh nourishment from nature which is more agreeable to the body. Still they do more exercise as they race horses and go hunting in search for their livelihood. As a result, the frequency and complexity of illness is less; their need for medicine is also less. (Ibn Khaldun, 1980, 2/76-77) Therefore, medicine is more advanced in towns than in deserts; the advancement in medicine is proportionate to their respective needs. This analysis suggests that it will be inappropriate to measure the level of medicine in desert with the scale of towns.

Ibn Khaldūn placed prophetic medicine within the socio-historical need of the deserts in which the Prophet lived. He explained that the people of the deserts developed medicine which they based on limited experimentation in accordance to the limited illness at that time. While some of their prescription might be valid, they are not based on natural law. Prophetic hadith was then placed within the socio-historical context of the Arabian Peninsula. According to him, such medicine has nothing to do with revelation because Prophet Muhammad was not sent to teach medicine but Sharīah. The medicine mentioned in religious tradition is of the (Bedouin) type. It is in no way part of the divine revelation. (Such medical matters) were merely (part of) Arab custom and happened to be mentioned in connection with the circumstances of the Prophet, like other things that were customary in his generation. They were not mentioned in order to imply as religious laws. Muhammad was sent to teach us the religious law. He was not sent to teach us medicine or any other ordinary matter. In connection with the story of the fecundation of the palms, he said: "You know more about your worldly affairs (than I)." (Ibn Khaldun, 1980, 3/150).

In order to support his view, Ibn Khaldūn further compared the Prophetic hadith on medicine to his advice on technical skill as reported in Sahihi Muslim. There the Prophet himself made a distinction between the instruction he gave meant to be legal and binding and that which is merely based on his technical experience. The hadith reads as follows: Anas reported that Allah's Messenger (may peace be upon him) happened to pass by the people who had been busy in grafting the trees. Thereupon he said: If you were not to do it, it might be good for you. (So they abandoned this practice) and there was a decline in the yield. He (the Holy Prophet) happened to pass by them (and said): What has gone wrong with your trees? They said: You said so and so. Thereupon he said: You have better knowledge (of a technical skill) in the affairs of the world." (Muslim, No. 2363). 
While Ibn Khaldūn believed that such medical prescription of hadith can be used to seek for divine blessing in true religious faith, he did not believe that it is instructive, meant to be binding. It follows that if any of such hadith is found to be inaccurate, that should not cast any doubt to the authority of hadith. Prophet was human and did things as required by his humanity disposition or to conform to the Arab custom. It is then wrong to measure the past with conditions available to the present.

\subsection{Evaluating the practicability of a hadith in the light of law of civilization}

This is another example of applying HCM in hadith by Ibn Khaldun. The way Ibn Khaldūn treated the ahadith related to the rise of Mahdī is an example for his above mentioned unique methodology. First he scrutinized and then discredited the chain of narrations that he knew and then he concluded that "These are all the traditions published by the religious authorities concerning the Mahdi and his appearance at the end of time. One has seen what they are like. Very few are above criticism.(Ibn Khaldun, 1980, 2/184).

Examining the Sufi understanding of the hadith on Mahdī, he observes that in some of them the time, the man, and the place are clearly indicated, but the predicted time passes, and there is no slightest trace of (the prediction coming true). Later he looks into the hadith in the light of the law of civilization and particularly 'așabiyyah. Earlier in his discussion about prophethood, Ibn Khaldūn enumerated signs by which prophets can be recognised and circumstances that nurture/sustain their emergence. One of these signs which is very central to Ibn Khaldūn's theory of the rise and fall of dynasty is the prestige the prophets enjoyed among their people. That is what he refers to as 'asabiyyah' (group feeling) which enable him to convey the message and protect him from any harm from his adversaries. (Ibn Khaldun, 1980, 1/188).

In his refute of hadith Mahdi, he invoked the principle and said that Mahdi hadith does not fit in. He says: "The truth one must know is that no religious or political propaganda can be successful, unless power and group feeling exist to support the religious and political aspirations and to defend them against those who reject them, until God's will with regard to them materializes. We have established this before, with natural arguments which we presented to the reader."(Ibn Khaldun,1980, 195).

On the basis of 'asabiyyah concept, Ibn Khaldun predicts that "If it is correct that a Mahdi is to appear" it will not be from Fatimids, Talibids or Quraysh, as different groups believes, because their group feeling no longer exists. However, to him the 
"only exception is a remnant of the Talibids-Hasanids, Husaynids, and Ja'farites- in the Hijaz, in Mecca, al-Yanbu', and Medina. They are spread over these regions and dominate them. They are Bedouin groups. They are settled and rule in different places and hold divergent opinions." So if a Mahdi is going to emerge then "he must be one of them, and God must unite them in the intention to follow him, until he gathers enough strength and group feeling to gain success for his cause and to move the people to support him."Ibn Khaldun, 1980, 1/196)

Analysing these two cases the researcher believes that he does not tend to reject the ahadith of medicine found in authentic books of hadith rather he is against its applicability in his time and it is not conveyed to the humanity as divine law. But in the second case he tends to deny the hadith as he questioned possibility of events mentioned in history works. I think he dares to do it due to his understanding that most of the narrations recorded in this regard are inauthentic. It is different from that of west, who tend to deny authentic hadith due to the contradictions with HCM.

\section{Conclusion}

The west started study of hadith with their sceptic mind. The method they used was 'historical critical method' rather than the methods of hadith criticism developed by the Muslim scholars who firmly believe that the Muhammed is Prophet of Almighty Allah. Moreover, western criticism of hadith can be viewed as an act of domination in which one worldview asserts its power over the another by dictating the terms by which the knowledge and the truth are established. Therefore, western discussions about the reliability of the hadith tradition are not neutral. The authenticity question is part of a broader over the power dynamic between Religion and Modernity and Islam and the west. (Brown197-208).

The Muslilm hadith tradition and the western academic study of Islamic origin have totally different methods even though to evaluate the authenticity of reports about the past. Muslim hadith scholars and jurists like Ibn Khaldun treated a report attributed to the Prophet prima facie as something he really said. A critical examination of a hadith was required only when a scholar had some compelling reason to doubt its authenticity. Furthermore, Muslim belief that the Prophet had been granted the knowledge of the unseen and intended his legacy to form the basis for the civilisation of Islam has meant that Muslims venerate the statements attributed to the Prophet before they doubt them. In short the scepticism towards hadiths was not their default setting. ( $/$ bid). 
Even though Ibn Khaldun has introduced the HCM, he never applied it as such to hadith because the miracles of the Prophet is beyond natural law and also most of the hadith are not about historical account but with binding nature. So his reading is reading of real believer in Allah who believes in the Prophet and their peculiarities. Moreover, he never denied the ahadith of medicine but he believe in it but disagree upon whether it could be used as such in present condition. However, the west questions the reliability of hadith itself. Regarding the ahadith related to Mahdi, the first preference he has given is to transmitter criticism and then only he goes to content criticism by using HCM.

Accusation of the west especially the Goldziher and his followers that the hadith scholars have ignored the content criticism is not true. We could find many examples of content criticism in classical text of hadith as Jonathan Brown noted in his article "How We Know Early Hadīth Critics Did Matn Criticism and Why It's So Hard to Find." Later Ibn al-Qayyim al-Jawziyyah has elaborated on it. He explained the standards that could be used to identify false hadith with ease. He mentioned 13 standards for matan criticism that could be summarised as follows: First: Hadith that contradict the alQur'an Second: Hadith that contradict other authenticated hadith Third: Hadith that contradict the basics of the syarak Fourth: Hadith that have a severe, aggravated or grievous connotation Fifth: Hadith that contradict authenticated historical facts Sixth: Hadith that have illogical connotations Seventh: Hadith that contradict reality Eight: Hadith that does that reflect the words of the Prophet The first three standards can be combined and called the syarak standards because it is based on the al-Qur'an and hadith plus the deductions (istinbat) made from both these sources. The remaining five standards can be combined as logical and realistic standards because it is based on the elements of logic and reality. In fact, that does not mean their content criticism is similar to that of Goldziher. They were not sceptic, but good believers in Allah and they believed the close relation between Prophet and the God. They believed that prophethood and miracles could not be evaluated by law of civilisation. Rather it should be studied through its own methods developed by hadith scholars.

\section{References}

Brown, A. C. Jonathan. (2010). Hadith: Muhammad's Legacy in the Medieval and Modern World. Oxford: Oneworld

Goldziher, Ignaz. (1969). Muslim Studies. Albany: State University of New York Press. Vol.2. 
Ibn Khaldun. (1980). The Muqaddimah: An Introduction to History. Tran. Franz Rosenthal. n.p.: Princeton University Press.

Itr, Nur al-Din. (1990). Manhaj al-Naqd fi Ulum al-Hadith. Dimishq: Dar al-Flkr

Muslim, Ibn al-Hajjaj al-Naysaburi. (1998). Sahih Muslim. Bayrut: Dar al-Kutub al-'Ilmiyyah.

Uri Rubin. (1998). The Prophet Muhammad and Islamic Sources, in Uri Rubin edited, The Life of Muhammad, Hampshire: Ashgate 